\title{
EKSTRAKSI GELATIN DARI TULANG IKAN KAKAP PUTIH (Lates calcarifer) DENGAN VARIASI KONSENTRASI ASAM HCI
}

\author{
Bhayu gita Bhernama*, Reni Silvia Nasution, Syarifah Ummayatun Nisa \\ Program studi kimia Universitas Islam Negeri Ar-Raniry Banda Aceh, NAD, Indonesia \\ Jln. Syeikh Abdur Rauuf Kopelma Darussalam, 23111 \\ *Email: deta.chavez1678@ gmail.com
}

\begin{abstract}
Extraction of Gelatin from Fish White Bone (Lates Calcarifer) with $\mathrm{HCl}$ Concentration Variance
\end{abstract}

\begin{abstract}
Gelatin is a food added ingredient used in emulsifiers, thickeners, food stabilizers. Gelatin is a type of protein in the form of gel obtained from the denaturation of skin, bone and fish tissue collagen denaturation. The process of making gelatin from the bones of white snapper (Lates calcarifer) uses the HCl acid method with the parameters of yield, water content, ash content, and protein content. The immersion process carried out with varoius of $\mathrm{HCl}$ acid concentration 3\%, 7\% and 11\%.The results show that the best value of\% yield at a concentration of 7\% of $1.90 \%, 10.16 \%$ water content. Ash content $3 \%$. Protein content is $3.25 \%$. FTIR spectrum revealed the presence of amida group at wave number $3269 \mathrm{~cm}^{-1}$, amide I; II; and Amida III sequentially at wave number $1656 \mathrm{~cm}^{-1} ; 1525.69$ $\mathrm{cm}^{-1} ; 1161.15 \mathrm{~cm}^{-1}$.
\end{abstract}

Keywords : Gelatin ; collagen ; Lates calcarifer ; FTIR

\begin{abstract}
ABSTRAK
Gelatin merupakan bahan tambah pangan yang digunakan dalam pengemulsi, pengental, penstabil makanan. Gelatin merupakan salah satu jenis protein yang berbentuk gel yang didapatkan dari hasil denaturasi kolagen kulit, tulang dan jaringan ikan. Proses ekstrak gelatin dari bahan tulang ikan kakap putih (Lates calcarifer) menggunakan asam $\mathrm{HCl}$ dengan parameter rendemen, kadar air, kadar abu, kadar protein dan analisis FTIR. Proses perendaman dilakukan variasi asam $\mathrm{HCl} 3 \%, 7 \%$ dan $11 \%$. Dari hasil penelitian didapatkan nilai $\%$ rendemen tertinggi pada konsentrasi $7 \%$ sebesar 1,90\%, dengan nilai kadar air 10,16\%, kadar abu 3,00\%, kadar protein 3,25\%. Dari spektrum FTIR didapatkan gugus Amida A pada bilangan gelombang $3269 \mathrm{~cm}^{-1}$, amida I ; II ; dan amida III secara berturut-turut pada bilangan gelombang $1656 \mathrm{~cm}^{-1} ; 1525,69 \mathrm{~cm}^{-1} 1 ; 161,15 \mathrm{~cm}^{-1}$.
\end{abstract}

Kata kunci : Gelatin ; ikan kakap putih ; FTIR

\section{PENDAHULUAN}

'Gelatin merupakan salah satu bahan tambahan pangan yang sering digunakan oleh industri makanan, dimana gelatin tersebut digunakan sebagai pengemulsi, pengental, penstabil, pengikat air, pembentuk gel, pengendap dan juga digunakan sebagai pembungkus makanan (Suryanti, Hadi, \& Peranginangin, 2006 ; Nurmilah, \& Mujdalipah, 2018 ; Darwin, Ridhay, Hardi, 2018) . Tidak hanya sebagai bahan tambah pangan, gelatin juga digunakan dalam industri kosmetik, obatobatan dan juga sebagai pembuat film (Iqbal, Anam, \& Ridwan., 2015 ; Nurilmala \& Jacoeb., 2017 ; Ridhay et al, 2018). Gelatin adalah protein dalam bentuk gel, didapatkan secara alami dari proses denaturasi panas dan hidrolisis kolagen kulit, tulang dan jaringan serat putih hewan (Atma, Ramdhani, Mustopa, \& Pertiwi., 2018) ; Gunawan, Suptijah, \& Uju, 2017 ; Ridhay et al, 2018). Pada proses denaturasi panas dan hidrolisis tersebut struktur tripel helix dari kolagen bergabung membentuk ikatan kovalen dengan tiga jenis peptida dari asam amino (Fransiskha, 2016). Susunan asam amino gelatin hampir sama dengan asam amino kolagen yaitu glisin, prolin dan hidroksiprolin. Asam amino gelatin terisi dua pertiga oleh glisin dan sepertiga lainnya diisi oleh prolin dan hidroksiprolin (Suryanti et al. 2006). Suryanti et al. (2006) juga menyatakan dalam artikelnya mengenai ekstraksi gelatin dari ikan kakap merah 
bahwa gelatin terbagi menjadi dua bagian, yaitu tipe A dan tipe B. Pembagian gelatin tersebut berdasarkan kepada proses pengolahannya. Gelatin tipe A diproses dengan cara merendam bahan baku dalam larutan asam, yang dikenal dengan sebutan proses asam. Sementara gelatin tipe B diproses dengan perendaman dalam larutan basa yang disebut sebagai proses basa. BPS (2015) dalam Gunawan et al. (2017) menyebutkan bahwa Indonesia belum bisa memenuhi kebutuhan akan gelatin dalam skala besar, sehingga dibutuhkan impor gelatin dari negara lain, seperti India, Cina, Jerman, Prancis, Argentina, Brazil dan Australia. BPS (2007) menuliskan Indonesia mengimpor gelatin sebesar $2.715 .782 \mathrm{~kg}$ yaitu senilai 9.535.128 dolar AS dari negaranegara pengimpor gelatin tersebut (Nurmilah \& Mujdalipah, 2018).

Gelatin impor, umumnya diproses dari bahan baku tulang dan kulit sapi ataupun babi yang berasal dari negara-negara yang penduduknya non muslim, sehingga menimbulkan keraguan akan status kehalalan gelatin tersebut. Untuk menghilangkan keraguan atas status kehalalan gelatin, dilakukan upaya dalam meminimalisir gelatin impor dengan mengganti sumber utama gelatin sapi atau babi dengan gelatin ikan (Gunawan et al. 2017). Hermanto, Hudzaifah \& Muawanah (2014) menjelaskan bahwa gelatin berbahan baku ikan memiliki perbedaan dengan gelatin berbahan baku mamalia, diantaranya perbedaan pada titik leleh dan kekuatan gelnya. Gelatin ikan memiliki titik leleh dan kekuatan gel yang lebih rendah daripada gelatin mamalia. Akan tetapi, viskositas dari gelatin ikan lebih tinggi dibanding gelatin mamalia.

Penelitian yang terkait dengan pemanfaatan kulit dan tulang ikan sebagai bahan baku gelatin telah banyak dilakukan. Permata et al. (2016) memanfaatkan tulang ikan lele sebagai bahan baku pembuatan gelatin melalui metode asam dengan melakukan variasi konsentrasi asam klorida $\mathrm{HCl}$. Pada konsentrasi $\mathrm{HCl} 4 \%$ dengan waktu ekstraksi 5 jam merupakan perlakuan yang terbaik menghasilkan rendemen gelatin sebesar $10,9 \%$. Karakteristik gelatin yang diperoleh yaitu $\mathrm{pH} 4$, kadar protein $=64,76$
$\%$, kadar air $=3,70 \%$, kadar abu $=13,37 \%$, kadar kalsium $=0,34 \%$, viskositas $=5,50$ $\mathrm{cp}$, bloom gel strength $=177$ gBloom . Nurmilah \& Mujdalipah, (2018) melakukan ekstraksi gelatin dari tulang ikan kakap menggunakan metoda asam. Asam yang digunakan adalah $\mathrm{HCl}, \quad \mathrm{H}_{2} \mathrm{SO}_{4}$ dan $\mathrm{CH}_{3} \mathrm{COOH}$. Gelatin terbaik yang dihasilkan sesuai dengan gelatin komersial sebagai gelatin pembanding adalah gelatin dengan perendaman menggunakan $\mathrm{H}_{2} \mathrm{SO}_{4}$ dengan konsetrasi 3\%. Fransiskha (2016) melakukan optimasi ekstraksi gelatin dari tulang ikan tuna dengan metoda asam. Pelarut yang digunakan adalah $\mathrm{HCl}$ dengan variasi konsentrasi sebesar 1, 3, 5, 7, 9 dan 11\%. Rendemen gelatin tertinggi diperoleh pada konsentrasi 3\% sebesar 5,03\% dengan kadar air 8,59\%, kadar abu 8,02\%, kadar lemak $0,27 \%$, kadar protein $80,2 \%$ dan kekuatan gel gelatin adalah 167,86 gram bloom. Ridhay et al. (2016) melakukan pembuatan gelatin dari tulang ikan cangkalang dengan menvariasikan pelarut asam, yaitu $\mathrm{HCl}$, $\mathrm{H}_{2} \mathrm{SO}_{4}, \mathrm{H}_{3} \mathrm{PO}_{4}, \mathrm{CH}_{3} \mathrm{COOH}, \mathrm{H}_{2} \mathrm{C}_{2} \mathrm{O}_{4}$, dan $\mathrm{C}_{6} \mathrm{H}_{8} \mathrm{O}_{7}$ pada konsentrasi $5 \%$ (b/v). Hasil yang diperoleh dengan rendemen tertinggi pada pelarut $\mathrm{H}_{3} \mathrm{PO}_{4}$ dengan kekuatan gel $39,6 \mathrm{~mm} / \mathrm{kg}$.s, viskositas $4,3784 \mathrm{cPs}$, kadar air 6,1576\% dan kadar abu 2,5974\%. Ridhay \& Hardi (2018) melakukan ekstraksi gelatin dari tulang ikan mujair dengan perendaman menggunakan asam sitrat $9 \%$. Atma et al. (2018) melakukan ekstraksi gelatin dari tulang ikan patin dengan menggunakan limbah buah nanas sebagai pengganti pelarut asam secara alami, karena buah nanas mengandung asam sitrat yang tinggi. Hasil yang diperoleh yaitu kadar air $8,59 \%$, abu $0,95 \%$, protein kasar $47,60 \%$ dan lemak $7,71 \%$.

Penelitian pemanfaatan kulit ikan sebagai bahan baku gelatin juga dilakukan oleh Rahmawati \& Pranoto (2012) terhadap kulit ikan belut dan lele dengan menggunakan pelarut asam asetat. Rendemen tertinggi terdapat pada ikan lele yaitu sebesar $22,01 \%$. Nurilmala \& Jacoeb (2017) melakukan karakterisasi gelatin dari kulit ikan tuna sirip kuning dengan perendaman menggunakan pelarut pada proses hidrolisis $\mathrm{CH}_{3} \mathrm{COOH} 0,05 \mathrm{M}$, suhu ekstraksi terbaik yang didapatkan $75^{\circ} \mathrm{C}$ 
dengan rendemen 17\%, $\mathrm{pH} 5,3$, kekuatan gel 1789,6 gf, viskositas 104,2 Cp. Gunawan et al. (2017) melakukan ekstraksi dan karakterisasi gelatin dari kulit ikan tenggiri dengan menggunakan pelarut pada proses hidrolisis adalah $\mathrm{CH}_{3} \mathrm{COOH}$. Suhu ektraksi yangs dilakukan pada suhu $70^{\circ} \mathrm{C}$ dengan rendemen yang dihasilkan $6,61 \pm 0,52 \%, \mathrm{pH}$ 5,47 , kekuatan gel 70,81 bloom, viskositas $5,51 \mathrm{cP}$, kandungan protein $86,78 \pm 0,07 \%$, air $7,69 \pm 0,12 \%$, lemak $0,71 \pm 0,07 \%$ dan abu $0,58 \pm 0,13 \%$. Samosir \& Idiawati, (2018) dalam artikel yang berjudul ekstraksi gelatin dari ikan toman dengan memvariasikan konsentrasi pelarut asam asetat dengan rendemen gelatin terbaik pada konsentrasi $0,5 \%$ sebesar 3,04\%.

Ikan kakap putih (Lates calcarifer) memiliki pertumbuhan yang cepat sehingga menjadikannya sebagai salah satu komoditas budidaya ikan yang diunggulkan. Ikan kakap putih (Lates calcarifer) banyak dikonsumsi oleh masyarakat di dalam dan luar negeri, dikarenakan ikan kakap putih (Lates calcarifer) ini memiliki kandungan omega3 , protein $20 \%$ dan lemak $5 \%$ (Windarto, Hastuti, Subandiyono \& Nugroho, 2019).

Dari beberapa penelitian tersebut diatas, masih sedikit yang melakukan ekstraksi gelatin dari bahan tulang ikan, terutama tulang ikan kakap putih (Lates calcarifer). Oleh karena itu, peneliti tertarik melakukan penelitian tentang ekstraksi gelatin dari tulang kakap putih (Lates calcarifer) dengan variasi konsentrasi asam klorida $(\mathrm{HCl})$ sebagai solusi untuk menjadikan tulang ikan sebagai sumber utama pembuatan gelatin halal. Untuk menentukan kualitas dari gelatin tulang ikan kakap putih (Lates calcarifer) dilakukan uji karakteristik berupa uji rendemen, kadar air, kadar abu, kadar protein dan analisis gugus fungsi menggunakan FTIR.

\section{BAHAN DAN METODE}

\section{Alat dan Bahan}

Alat yang digunakan pada penelitian ini, antara lain peralatan gelas (duran), Oven Inkubator (GP-45BE), timbangan analitik, tanur, water bath, dan FTIR (Shimadzu).
Bahan yang digunakan pada penelitian ini yaitu tulang ikan kakap putih (Lates calcarifer) yang didiambil dari tempat pengolahan ikan Lampulo, Banda Aceh, akuades, natrium hidroksida $(\mathrm{NaOH}) \quad 45 \%$ dan natrium hidroksida $(\mathrm{NaOH}) \quad 0,1 \quad \mathrm{~N}$ (Merck), natrium sulfat $\left(\mathrm{Na}_{2} \mathrm{SO}_{4}\right)$ (Merck), tembaga (II) sulfat $\left(\mathrm{CuSO}_{4}\right)$ (Merck), logam Zink (Zn) (Merck), indikator phenolphthalein (PP) (Merck), indikator metil orange (MO) (Merck), asam sulfat $\left(\mathrm{H}_{2} \mathrm{SO}_{4}\right)$ (Merck) dan asam klorida $(\mathrm{HCl})$ p.a.

\section{Metode}

Tulang ikan kakap putih (Lates calcarifer) yang diambil dari tempat pengolahan ikan Lampulo terlebih dahulu dilakukan uji taksonomi. Kemudian dilakukan pembuatan gelatin dengan empat proses, tahapannya yaitu degreasing, demineralisasi, ekstraksi dan yang terakhir adalah proses pengeringan. Setelah itu dilakukan karakterisasi gelatin yaitu rendemen, kadar air, kadar abu, dan kadar protein serta dianalisis gugus fungsinya menggunakan FTIR.

\section{Ekstraksi Gelatin}

a) Degreasing

Proses degreasing mengacu pada metoda yang digunakan oleh Ridhay, et al. (2016) dan dimodifikasi. Proses diawali dengan cara merendam tulang ikan dengan air mendidih selama \pm 30 menit, kemudian sisa daging dan lemak yang masih menempel dibersihkan dari tulang. Selanjutnya tulang ikan dijemur hingga kering dan dipotong-potong dengan ukuran $\pm 1 \mathrm{~cm}$

b) Demineralisasi

Sebanyak 75 gram tulang ikan kakap putih direndam dalam larutan asam klorida $(\mathrm{HCl})$ dengan variasi konsentrasi 3\%, 7\% dan $11 \%$ dengan waktu perendaman selama 48 jam (sampai terbentuk tulang lunak (ossein)), setelah itu disaring. Perbandingan yang dimiliki pada tulang ikan dengan pelarut yaitu sebesar 1:3 (b/v) Kemudian tulang lunak (ossein) 
tersebut dicuci dengan akuades hingga pH 6-7 (netral) kemudian disaring.

c) Ekstraksi

Ossein (tulang lunak) pada $\mathrm{pH}$ netral hasil demineralisasi, dilakukan proses ekstraksi menggunakan water bath pada suhu $70^{\circ} \mathrm{C}$ selama $\pm 3 \mathrm{jam}$. Kemudian filtrat disaring.

d) Pengeringan

Filtrat hasil ekstraksi dikeringkan dalam oven pada suhu $50-60^{\circ} \mathrm{C}$ selama 24 jam (hingga terbentuk gelatin)

\section{Karakterisasi gelatin dari tulang kakap putih (Lates calcarifer)}

Karakterisasi gelatin dari tulang kakap putih (Lates calcarifer) mencakup pengujian rendemen, kadar air, kadar abu dan kadar protein. Pengujian ini dilakukan 3 kali pengulangan. Analisis gelatin dari tulang kakap putih (Lates calcarifer) menggunakan statistik uji $t$ dan gugus fungsi menggunakan FTIR.

\section{HASIL DAN PEMBAHASAN}

\section{Identifikasi morfologi}

Tahap awal penelitian ekstraksi dan karakterisasi gelatin dari tulang kakap putih (Lates calcarifer) ini adalah penentuan taksonomi dari ikan kakap putih (Lates calcarifer), sehingga diperoleh hasil antara lain : Kingdom : Animalia, Phylum : Chordata, Sub phylum : Vetebrata, Classis : Pinces Sub class : Teleostei, Orde : Percomorphi, Familia : Centropomidae, Genus : Lates, Species : Lates calcarifer. Berdasarkan taksonomi yang telah dilakukan tersebut, ikan kakap putih yang digunakan dapat dilihat pada Gambar 1.

\section{Ekstraksi gelatin tulang kakap putih (Lates calcarifer)}

Proses pembuatan gelatin ini terdiri dari tiga tahapan awal yaitu pembersihan (degreasing), proses penghilangan kandungan mineral (demineralisasi) dan terakhir proses pemisahan (ekstraksi). Tahap pertama adalah proses pembersihan tulang ikan kakap putih (Lates calcarifer) dari daging dan lemak yang menempel pada tulang sehingga dapat digunakan pada proses selanjutnya. Tulang ikan kakap putih yang telah dibersihkan dan dikeringkan dapat dilihat pada Gambar 2.

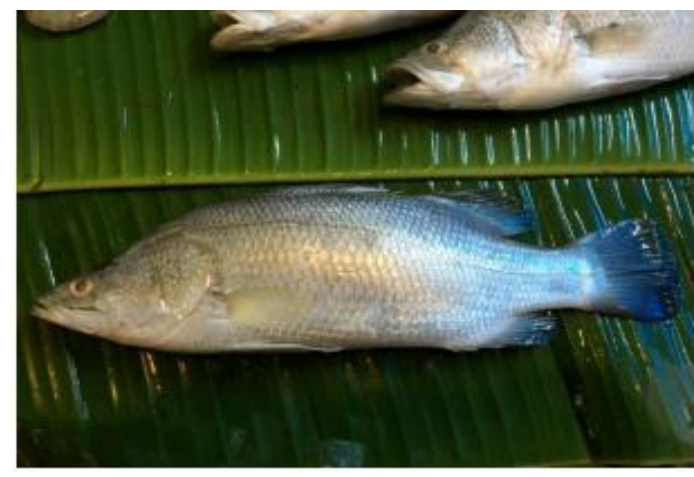

Gambar 1. Ikan kakap putih (Lates calcarifer) (Sumber : Dokumentasi pribadi)

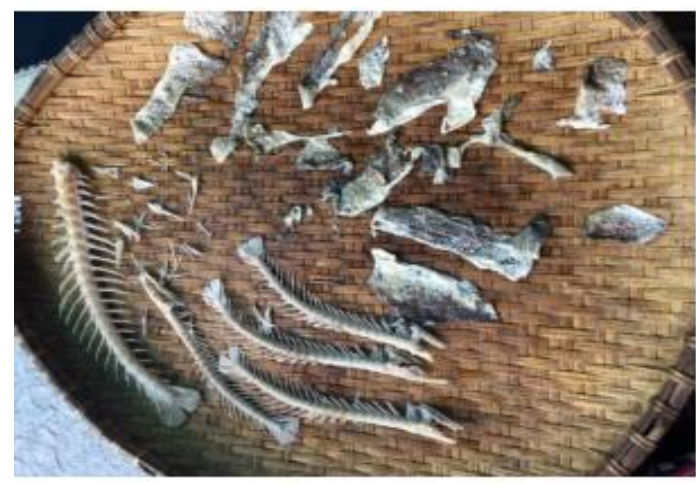

Gambar 2. Tulang ikan kakap putih putih (Lates calcarifer) yang telah dikeringkan dan dibersihkan (Sumber : Dokumentasi pribadi)

Tahap kedua adalah proses penghilangan mineral yang terdapat pada tulang ikan kakap putih (Lates calcarifer) berupa penghilangan kalsium dan garam. Perendaman tulang ikan kakap putih menggunakan $\mathrm{HCl}$ sampai menjadi lunak dinamakan ossein. Ridhay \& Hardi (2018) menyatakan selain proses demineralisasi proses lain yang terjadi adalah proses swelling (pengembungan tulang). Ridhay \& Hardi (2018) juga menuliskan pada proses ini terjadi pemasukan proton kedalam struktur tulang yang kehilangan mineral (adanya ruang kosong pada tropokolagen). Reaksi yang terjadi pada ossein (tulang ikan 
lunak) dengan asam pada proses perendaman sebagai berikut :

$$
\begin{gathered}
\mathrm{Ca}_{3}\left(\mathrm{PO}_{4}\right)_{2(\mathrm{aq})}+6 \mathrm{HCl}_{\text {(aq) }} \rightarrow 3 \mathrm{CaCl}_{2} \text { (aq) } \\
2 \mathrm{H}_{3}\left(\mathrm{PO}_{4}\right)_{(\text {aq })}(\text { Huda et al. 2013) }
\end{gathered}
$$

Tahap ketiga yaitu proses ekstraksi tulang kakap putih (Lates calcarifer) menggunakan akuades. Proses ekstraksi ini menggunakan water bath pada suhu $70^{\circ} \mathrm{C}$ selama \pm 3 jam. Proses ekstraksi yang dilakukan bertujuan agar ikatan hidrogen pada tropokolagen rusak. Setelah 3 jam disaring dan filtrat yang dihasilkan dikeringkan menggunakan oven suhu $60^{\circ} \mathrm{C}$ selama $24 \mathrm{jam}$. Penggunaan suhu $60^{\circ} \mathrm{C}$ ini dilakukan agar tidak terjadi denaturasi ikatan polipeptida yang terdapat pada tulang ikan. Setelah 24 jam, filtrat tersebut diambil dari dalam oven filtrat yang sebelumnya berbentuk cairan setelah dilakukan pengeringan membentuk lapisan tipis. Lapisan ini diambil dengan cara dikerok hingga membentuk serbuk. Serbuk gelatin ini kemudian dilakukan karakterisasi berupa penentuan rendemen, kadar abu, kadar air, kadar protein dan analisis gugus fungsi menggunakan FTIR. Gambar hasil ekstraksi gelatin dari tulang ikan kakap putih dengan perendaman menggunakan $\mathrm{HCl}$ dapat dilihat pada Gambar 3 dibawah ini :

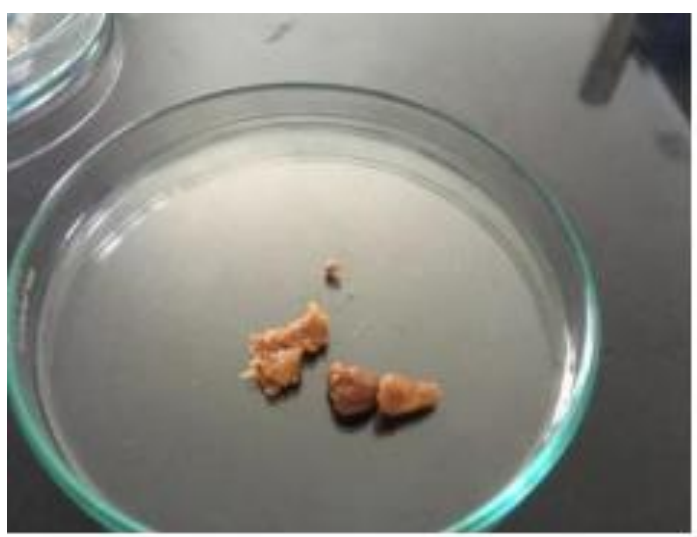

Gambar 3. Gelatin dari tulang kakap putih (Lates calcarifer) hasil perendaman menggunakan $\mathrm{HCl}$ (Sumber : Dokumentasi pribadi)

Ekstraksi gelatin dari tulang kakap putih (Lates calcarifer) menggunakan variasi konsentrasi $\mathrm{HCl} 3 \%, 7 \%$ dan $11 \%$ yang digunakan sebagai larutan perendaman dalam proses demineralisasi tulang kakap putih (Lates calcarifer). Proses demineralisasi ini dilakukan dengan perendaman selama 48 jam sehingga proses pemutusan ikatan hidrogen paa struktur kolagen berlangsung baik. Samosir \& Idiawati (2018) menyatakan bahwa proses perendaman dengan menggunakan asam ini untuk mengubah kolagen yang berantai tiga menjadi kolagen berantai tunggal. Selain itu, proses perendaman juga mengakibatkan pengembungan/pembengkakan (swelling). Proses ini dapat membuang zat-zat atau material-material yang tidak dibutuhkan, hal ini dikarenakan terdapatnya ruang kosong pada tropokalogen sehingga ion $\mathrm{H}^{+}$dari senyawa asam akan masuk dan berinteraksi dengan gugus karboksil dan mengubah ikatan pada tropokolagen (Samosir \& Idiawati, 2018). Proses ekstraksi dengan air hangat akan memutuskan ikatan hidrogen dan memecahkan ikatan kovalen yang terdapat pada rantai tripel helix kolagen sehingga menghasilkan rantai kolagen yang larut dalam air (Hermanto, Hudzaifah \& Muawanah, 2014). Dari Gambar 3 tersebut terlihat warna gelatin yang dihasilkan kuning terang.

\section{Karakterisasi gelatin dari tulang kakap putih (Lates calcarifer)}

\section{Rendemen}

Penelitian ekstraksi dan karakterisasi gelatin dari tulang kakap putih (Lates calcarifer) dengan memvariasikan konsentrasi $\mathrm{HCl} \mathrm{3,7}$ dan $11 \%$ didapatkan data hasil rendemen pada Tabel 1. berikut :

Tabel 1. Hasil rendemen gelatin kakap putih (Lates calcarifer) menggunakan pelarut $\mathrm{HCl}$ dengan variasi konsentrasi 3\%, 7\% dan $11 \%$

\begin{tabular}{lll}
\hline \multirow{2}{*}{$\begin{array}{l}\text { Pelarut } \\
\text { Solven) }\end{array}$} & $\begin{array}{l}\text { Konsentrasi } \\
\text { (Consentration) }\end{array}$ & \begin{tabular}{l} 
Nilai $\begin{array}{l}\text { rendemen } \\
\text { (yield value } \\
(\%))\end{array}$ \\
\hline $\mathrm{HCl}$
\end{tabular} \\
$\begin{array}{lll}\text { (Hydrochloric } \\
\text { acid) }\end{array}$ & $3 \%$ & 1,44 \\
\cline { 2 - 3 } & $1 \%$ & 1,90 \\
\hline
\end{tabular}

Berdasarkan Tabel 1 diatas konsnetrasi $4 \%$ ke konsentrasi $7 \%$ nilai rendemen 
meningkat dan pada konsentrasi $11 \%$ nilai rendemen kembali menurun, kemudian diambil rendemen terbaik pada konsentrasi $7 \%$ sebesar $1,90 \%$ dan diambil sebagai dasar uji karakterisasi gelatin dari tulang kakap putih (Lates calcarifer).

Konsentrasi asam yang tinggi menyebabkan gelatin mengalami hidrolisis sehingga terjadi penurunan jumlah gelatin. Rendah atau tingginya suatu rendemen yang terjadi disebabkan oleh pengaruh ion $\mathrm{H}^{+}$ yang mengalami hidrolisis dari kolagen rantai tripel helix menjadi kolagen rantai tunggal (Samosir et al., 2018). Nilai rendemen terendah pada penggunaan pelarut $\mathrm{HCl} 11 \%$, hal ini diakibatkan karena pelarut $\mathrm{HCl} 11 \%$ menghasilkan proton lebih banyak sehingga terjadi seringnya terjadi tumbukan garam kalsium dan protein tulang ikan dengan pelarut asam. Penggunaan pelarut asam dengan konsentrasi yang tinggi mempermudah putusnya ikatan peptida pada tropokolagen yang menyebabkan protein juga ikut larut dalam pelarut asam.

Permata, Widiastri, Sudaryanto, \& Anteng (2016) melakukan ekstraksi gelatin dari tulang ikan lele menggunakan variasi $\mathrm{HCl} 2 \%, 4 \%, 6 \%$, dan $8 \%$ sebagai larutan perendaman ikan tulang lele pada proses demineralisasi. Dari hasil tersebut didapatkan nilai rendemen tertinggi pada konsentrasi $4 \%$ pada waktu 5 jam sebesar 10, 90\%. Semakin tinggi konsentrasi $\mathrm{HCl}$ rendemen yang dihasilkan juga akan semakin tinggi hingga pada suatu titik konsentrasi dan kemudian turun kembali. Hal ini disebabkan, konsentrasi ion $\mathrm{H}^{+}$ dalam larutan asam mengkonversi kolagen lebih mudah menjadi gelatin. Akan tetapi, jika konsentrasi ion $\mathrm{H}^{+}$terlalu banyak mengakibatkan kolagen pada tulang ikan mengalami destruksi sehingga kolagen tidak terkonversi menyeluruh menjadi gelatin. Penentuan nilai rendemen ini dilakukan untuk mengetahui tingkat keefektifan dan keefisiensian proses ekstraksi yang telah dilakukan pada proses pembuatan gelatin (Darwin, Ridhay \& Hardi, 2018 ; Ridhay, Musafira \& Nurhaeni 2016). Fransiskha (2016) melakukan optimasi gelatin pada tulang ikan tuna dengan mengunakan variasi pelarut asam klorida 1, 3, 5, 7, 9 dan11\%. Didapatkan nilai rendemen tertinggi pada konsentrasi $3 \%$ sebesar $5,03 \%$. Hal ini disebabkan perendaman tulang ikan dengan konsentrasi asam yang terlalu tinggi mengakibatkan terurainya (terdegradasi) komponen-komponen kolagen yang semakin banyak. Hasil rendemen gelatin dari tulang ikan kakap putih dengan perendaman menggunakan $\mathrm{HCl} 7 \%$ sebesar $1,90 \%$.

Tabel 2. Perbandingan nilai karakterisasi gelatin dari ikan kakap putih (Lates calcarifer) menggunakan $\mathrm{HCl}$, gelatin komersil, gelatin berdasarkan SNI 06-3735-1995 dan GMIA (Gelatin Handbook), dan JECFA

\begin{tabular}{|c|c|c|c|c|c|c|}
\hline & & $\begin{array}{l}\text { Gelatin } \\
\text { Gelatin }\end{array}$ & & & & \\
\hline $\begin{array}{l}\text { Karakteristik } \\
\text { Characteristics }\end{array}$ & $\begin{array}{l}\text { Tulang ikan } \\
\text { kakap putih } \\
\text { (Lates } \\
\text { calcarifer) } \\
(\mathrm{HCl} 7 \%)\end{array}$ & $\begin{array}{l}\text { Komersil } \\
\text { commercial } \\
\text { (Permata et } \\
\text { al., 2016) }\end{array}$ & $\begin{array}{l}\text { Komersil } \\
\text { commercial } \\
\text { (Fulanah, } \\
\text { 2012) }\end{array}$ & $\begin{array}{l}\text { Indonesia } \\
\text { nation } \\
\text { Standard No. } \\
\text { 06-3735- } \\
1995 \\
\text { (SNI No. 06- } \\
\text { 3735-1995) }\end{array}$ & $\begin{array}{l}\text { GMIA } \\
\text { (GMIA, } \\
2019)\end{array}$ & $\begin{array}{l}\text { JECFA (Food } \\
\text { and } \\
\text { Agricultural } \\
\text { Organization } \\
\text { of the United } \\
\text { Nations, } \\
2004 \text { ) }\end{array}$ \\
\hline $\begin{array}{l}\text { Rendemen }(\%) \\
\text { Yield }(\%)\end{array}$ & 1,90 & - & - & - & - & - \\
\hline $\begin{array}{l}\text { Kadar Air }(\%) \\
\text { Water content }(\%)\end{array}$ & 10,16 & 11,5 & 10,95 & Max 16 & Max 15 & Max 18 \\
\hline $\begin{array}{l}\text { Kadar Abu (\%) } \\
\text { Ash content }(\%)\end{array}$ & 3,00 & 0,77 & 1,51 & $\operatorname{Max} 3,25$ & $\begin{array}{l}\operatorname{Max} \\
0,30 \quad- \\
2,00\end{array}$ & $\operatorname{Max} 2$ \\
\hline $\begin{array}{l}\text { Kadar Protein }(\%) \\
\text { Protein content } \\
(\%)\end{array}$ & 3,25 & 85,01 & 79,40 & - & $>90,00$ & - \\
\hline
\end{tabular}


Hasil rendemen ini kecil dibandingkan dengan penelitian yang dilakukan oleh Fransiskha (2016) dimana perendaman tulang ikan tuna menggunakan $\mathrm{HCl} 7 \%$ selama 4 hari, disebabkan oleh proses perendaman yang terlalu lama dan konsentrasi $\mathrm{HCl}$ yang besar, sehingga komponen-komponen mineral, asam amino serta kolagen yang terdapat dalam tulang ikan kakap putih ini terurai terlalu banyak. Dari hasil analisis rendemen yang telah dilakukan sebanyak tiga kali perlakuan perendaman menggunakan $\mathrm{HCl} 7 \%$, didapatkan standar deviasi 0,042 sehingga dilakukan uji statistik rata-rata rendemen gelatin dari tulang kakap putih (Lates calcarifer). Hasil menunjukan bahwa nilai $\mathrm{t}_{\text {hitung }}<\mathrm{t}_{\text {tabel }}$ yang artinya data tersebut signifikan.

Untuk uji karaktristik gelatin dari tulang kakap putih (Lates calcarifer) yang dihasilkan dapat dibandingkan dengan standar nasional Indonesia dan standar Internasional, seperti yang tercantum pada Tabel 2. Berdasarkan Tabel 2, kadar air, kadar abu dari tulang ikan kakap putih (Lates calcarifer) masih memenuhi standar SNI No. 06-3735-1995. Akan tetapi belum memenuhi standar internasional GMIA dan JECFA. Begitu juga dengan kadar protein dibawah standar internasional GMIA.

\section{Kadar air}

Kadar air pada proses pembuatan gelatin dari tulang kakap putih (Lates calcarifer) sangat berpengaruh terdapat tekstur, mutu, rasa dan masa penyimpanan (Junianto, Kiki Haetami, \& Maulina, 2006 ; Iqbal, Anam \& Ridwan., 2015 ; Ridhay \& Hardi, 2018 ; Permata, Widiastri, Sudaryanto, \& Anteng., 2016 ; Pertiwi, Atma, Mustopa, \& Maisarah., 2018 ; (Rachmania, Nisma \& Mayangsari., 2013). Kadar air dalam produk pangan sangat penting dilakukan pengujian karena mempengaruhi kualitas produk pangan tersebut, hal ini dikarenakan air merupakan tempat aktivitas mikroba, bakteri, enzim dan aktivitas kimia yang menyebabkan perubahan tekstur, warna, rasa dan aroma. Kadar air gelatin dari tulang kakap putih (Lates calcarifer) dengan konsentrasi $\mathrm{HCl}$ $7 \%$ sebesar $10,16 \%$ dan masih dalam batas standar nasional Indonesia SNI No. 063735-1995 dan standar Internasional GMIA serta JECFA. Kadar air gelatin tulang kakap putih (Lates calcarifer) dengan rendemen pada konsentrasi $\mathrm{HCl} 7 \%$ ini, lebih besar dibandingkan Permata et al., (2016) melakukan perendaman tulang ikan lele dengan larutan asam klorida $(\mathrm{HCl}) \quad 4 \%$ menghasilkan kadar air 3,7\%. Fransiskha, (2016) melakukan perendaman tulang ikan tuna dengan $\mathrm{HCl} 3 \%$ menghasilkan kadar air $8,59 \%$. Kandungan air didalam gelatin yang masih ada, dikarenakan pada proses pengeringan tulang ikan yang dilakukan tidak terlalu kering.

Analisis kadar air dengan tiga kali perlakuan didapatkan standar deviasi 0,37 sehingga dapat dihitung uji rerata, hasil $\mathrm{t}_{\text {hitung }}<\mathrm{t}_{\text {tabel }}$ yang dapat diambil kesimpulan bahwa hasil uji rerata signifikan.

\section{Kadar $a b u$}

Kadar abu merupakan tahapan pengujian terhadap zat anorganik sisa hasil pembakaran suatu bahan organik dari makanan. Pertiwi, Atma, Mustopa, \& Maisarah (2018) menjelaskan tinggi atau rendah suatu kadar abu berasal dari mineralmineral yang ada pada sampel uji dan juga proses demineralisasi pada saat pembuatan gelatin. Selain itu, kadar abu juga melihat berhasil atau tidak proses ekstraksi yang dilakukan. Apabila kadar abu semakin rendah, tingkat kemurnian semakin tinggi. Nilai kadar abu gelatin tulang kakap putih (Lates calcarifer) pada perendaman $\mathrm{HCl} 7 \%$ sebesar 3\%. Berdasarkan standar nasional Indonesia SNI No. 06-3735-1995 kadar abu yang dihasilkan dari gelatin tulang ikan kakap putih (Lates calcarifer) ini masih dalam batas standar, begitu juga dengan standar Internasional GMIA dan JECFA. Kadar abu yang dihasilkan diindikasi merupakan kalsium. Huda et al., 2013 menjelaskan bahwa kalsium yang terdapat pada tulang ikan akan bereaksi dengan asam membentuk ion calsium $\left(\mathrm{Ca}^{2+}\right)$ yang terlarut dalam pelarut. Akan tetapi ion kalsium yang tertinggal pada tulang ikan akan terekstrak bersama gelatin.

Kadar abu dari penelitian ini masih tergolong besar jika dibandingkan dengan kadar abu yang dihasilkan dari proses 
ekstraksi gelatin ikan tulang patin dengan pelarut asam sitrat menghasilkan kadar abu 0,38\% (Pertiwi et al. 2018), gelatin dari tulang ikan patin menggunakan limbah buah nanas dengan kadar abu 0,95\% (Atma, Ramdhani, Mustopa, Pertiwi, \& Maisarah, 2018), gelatin dari tulang ikan cangkalang dengan pelarut $\mathrm{HCl} 5 \%$ dengan kadar abu 1,397\% (Ridhay, Musafira, Nurhaeni, Nurakhirawati, \& Khasanah, 2016), gelatin dari ikan tuna menggunakan pelarut $\mathrm{HCl} 3 \%$ menghasilkan kadar abu sebanyak 8,02\% (Fransiskha, 2016), kadar abu dari gelatin tulang ikan lele dengan perendaman $\mathrm{HCl} 4 \%$ sebesar 13,37\% (Permata Widiastri, Sudaryanto, \& Anteng, 2016). Saputra, Widiastuti, \& Supriadi (2015) menyatakan bahwa kadar abu merupakan mineralmineral hasil penguraian yang tertinggal pada proses ekstraksi. (Suptijah et al., 2013) juga menyatakan bahwa besar atau kecil nilai suatu kadar abu dipengaruhi oleh proses penguraian mineral pada waktu pencucian. Banyaknya mineral yang terurai maka kadar abu juga akan berkurang. Mineral-mineral yang belum terlepas dari kolagen selama pencucian dan penyaringan itulah yang terbawa saat proses pengabuan. Kadar abu dari gelatin tulang kakap putih (Lates calcarifer) dengan konsentrasi $\mathrm{HCl}$ 7\% masih tergolong besar. Dalam artikelnya Huda et al. (2013) menjelaskan semakin tinggi pelarut asam yang digunakan maka kalsium yang terlarut juga semakin banyak dan menyebabkan kalsium pada ossein berkurang. Penurunan kalsium pada ossein ini yang menjadi salah satu penyebab penurunan kadar abu. Karena calsium yang terekstrak menjadi lebih sedikit.

Hasil analisis yang dilakukan sebanyak tiga kali perlakuan terhadap kadar abu didapatkan standar deviasi 0,26 dengan nilai rerata $t_{\text {hitung }}<t_{\text {tabel }}$ dapat diambil kesimpulan bahwa kadar abu mempengaruhi kualitas gelatin yang dihasilkan.

\section{Kadar Protein}

Kadar protein gelatin yang dihasilkan dari proses ekstraksi tulang kakap putih (Lates calcarifer) dengan perendaman $\mathrm{HCl}$ 7\% menggunakan metoda Kjeldahl. Metoda ini sering dilakukan untuk menentukan kadar protein pada makanan. Kadar protein yang dihasilkan dari gelatin tulang ikan kakap putih (Lates calcarifer) menggunakan pelarut $\mathrm{HCl} 7 \%$ sebesar 3,25\%. Kadar protein yang dihasilkan sangat rendah dan tidak sesuai dengan kadar protein Internasional dan kadar protein gelatin komersil. Kadar protein menurut GMIA $>90,00$ dan komersil yang didapat oleh Permata et al. (2016) sebesar 85,01. Hal ini disebabkan karena tulang ikan yang digunakan tidak dalam keadaan segar, dikarenakan ikan sebelum diolah disimpan beberapa hari.

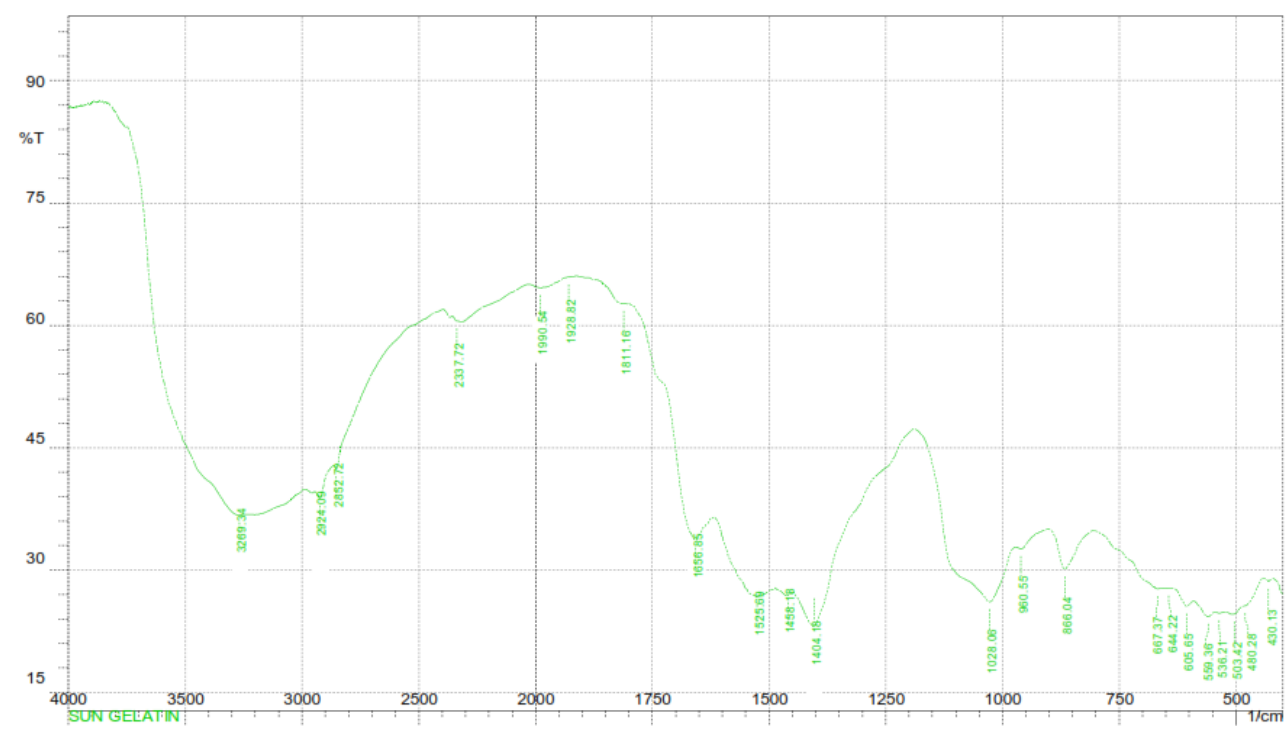

Gambar 4. Spektrum FTIR gelatin tulang kakap putih (Lates calcarifer)

(Sumber: Dokumentasi pribadi ) 


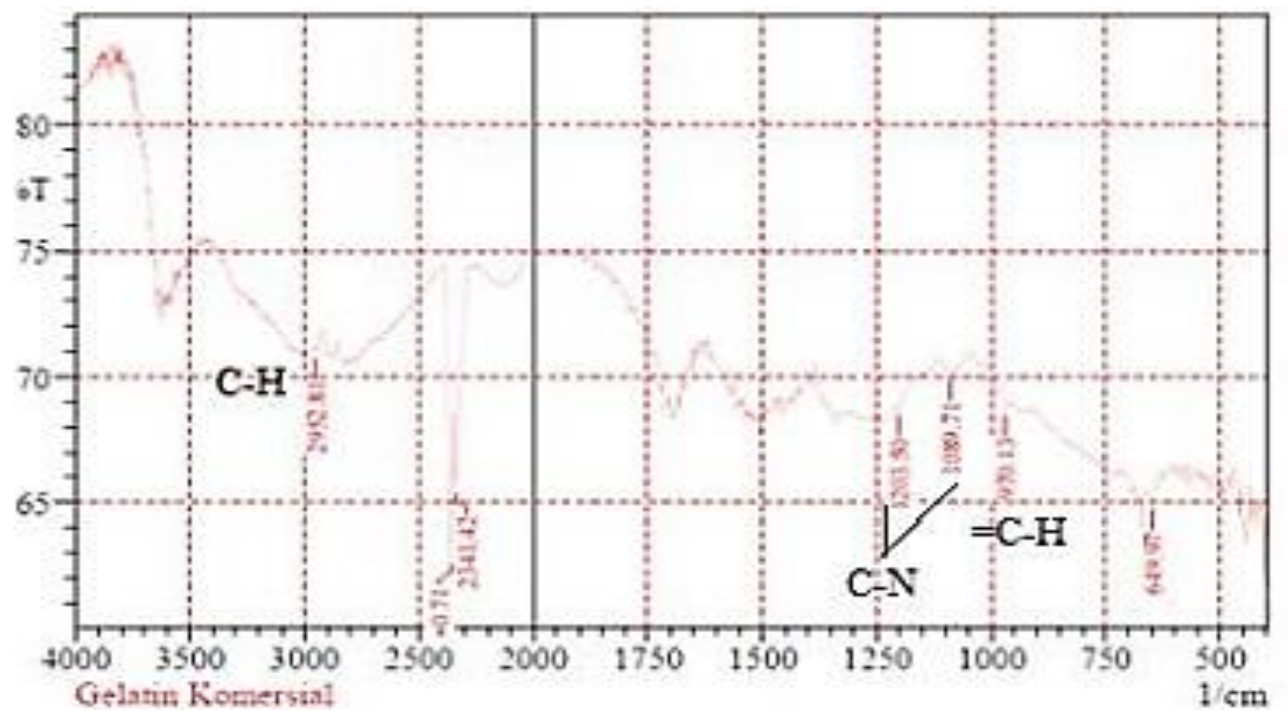

Gambar 5. Spektrum FTIR dari gelatin komersial

(Sumber : Permata, dkk(2016))

Penggunaan pelarut asam pada saat demineralisasi dan proses ekstraksi juga menyebabkan protein mengalami denaturasi sehingga mempengaruhi kadar protein yang dihasilkan (Saputra et al., 2015). Rachmania et al. (2013) menjelaskan bahwa kadar protein terbentuk akibat dari proses pemanasan. Apabila proses pemanasan dilakukan berlebih maka jumlah protein bertambah. Suptijah et al. (2013) juga menjelaskan bahwa tinggi atau rendahnya kadar protein dipengaruhi oleh pelarut pada proses perendaman yang dilakukan. Hal ini terjadi karena pada proses perendaman terjadi reaksi pemutusan hidrogen dan pelepasan komponen kolagen.

Hasil analisis rerata statistik yang dilakukan sebanyak tiga kali perlakuan didapatkan standar deviasi untuk kadar protein 0,132 dengan nilai rerata $t_{\text {hitung }}<t_{\text {tabel }}$, dapat diambil kesimpulan bahwa hasil uji rerata signifikan.

\section{Analisis FTIR}

Analisis FTIR digunakan untuk menganalisis struktur molekul gelatin, struktur molekul gelatin dari tulang kakap putih (Lates calcarifer), dibandingkan dengan gelatin komersil dan standar gelatin ikan. Gelatin yang dianalisis dengan metoda FTIR adalah gelatin yang telah dilakukan perendaman menggunakan pelarut $\mathrm{HCl} 7 \%$. Perbandingan spektrum IR gelatin dari tulang kakap putih (Lates calcarifer) dengan IR pembanding dapat dilihat pada Gambar 4 dan 5.

Pada dasarnya gugus fungsional gelatin terbagi menjadi empat bagian, yaitu amida A, amida I, amida II dan amida III. Amida A dapat dilihat pada kisaran panjang gelombang $3600-2300 \mathrm{~cm}^{-1}$, amida I dapat dilihat pada kisaran panjang gelombang $1636-1661 \mathrm{~cm}^{-1}$, amida II dapat dilihat pada kisaran panjang gelombang $1560-1335 \mathrm{~cm}^{-1}$ dan amida III dapat dilihat pada kisaran panjang gelombang 1300-1200 cm (Hermanto, Hudzaifah \& Muawanah, 2014). Dari Tabel 3 terlihat bahwa serapan maksimum pada gugus fungsi amida A, I, II dan III dari gelatin tulang ikan kakap putih (Lates calcarifer) tidak berbeda jauh dari penyerapan pada gugus fungsi gelatin pembanding, yaitu gelatin komersil. Gunawan, Suptijah, \& Uju (2017) menjelaskan bahwa gelatin pada serapan amida A terjadi akibat $\mathrm{N}-\mathrm{H}$ mengalami proses renggangan dari ikatan hidrogen dan asam amino prolin. Amida I adalah sisa amida dari gelatin, amida II struktur $\alpha$ helix dan asam amino prolin, amida III merupakan rantai tripel helix menjadi $\alpha$ helix akibat denaturasi molekul kolagen menjadi gelatin. 
Tabel 3. Perbandingan spektrum FTIR dari tulang kakap putih (Lates calcarifer)

\begin{tabular}{|c|c|c|c|c|}
\hline \multirow[t]{2}{*}{$\begin{array}{l}\text { Gugus Fungsi Amida } \\
\text { Amida Function Group }\end{array}$} & \multicolumn{4}{|c|}{$\begin{array}{c}\text { Gelatin/Gelatin } \\
\text { Panjang gelombang } \mathrm{cm}^{-1} \\
\text { Wavenumbre } \mathrm{cm}^{-1}\end{array}$} \\
\hline & $\begin{array}{l}\text { Tulang } \\
\text { ikan Kakap } \\
\text { Putih } \\
\text { Fish bone } \\
\text { of Lates } \\
\text { calcarifer }\end{array}$ & $\begin{array}{l}\text { Komersial } \\
\text { Comercial } \\
\text { (pembanding/ } \\
\text { comparison) } \\
\text { (Permata et al., 2016) }\end{array}$ & $\begin{array}{l}\text { Tulang ikan lele } \\
\text { dengan pelarut } \\
\mathrm{HCl} 4 \% \\
\text { Catfish bone with } \\
4 \% \mathrm{HCl} \text { solvent } \\
\text { (Permata et al., } \\
\text { 2016) }\end{array}$ & $\begin{array}{l}\text { Tulang Ikan Mujair } \\
\text { dengan pelarut } \\
\text { asam sitrat 9\% } \\
\text { Mujair Fish Bone } \\
\text { with 9\% Citric Acid } \\
\text { Solvent } \\
\text { (Darwin, Ridhay, } \\
\text { Hardi, 2018). }\end{array}$ \\
\hline $\begin{array}{l}\text { A } \\
\left(3600-2300 \mathrm{~cm}^{-1}\right) \\
(\mathrm{NH})\end{array}$ & 3269 & $2952,81 \mathrm{~cm}-1$ & $\begin{array}{l}2852,52 \mathrm{~cm}-1 \mathrm{dan} \\
2923,88 \mathrm{~cm}-1\end{array}$ & $2379,19 \mathrm{~cm}-1$ \\
\hline $\begin{array}{l}\text { I } \\
\left(1636-1661 \mathrm{~cm}^{-1}\right) \\
(\mathrm{C}=\mathrm{O})\end{array}$ & 1656 & $1700.00 \mathrm{~cm}-1$ & $1743,53 \mathrm{~cm}-1$ & - \\
\hline $\begin{array}{l}\text { II } \\
\left(1560-1335 \mathrm{~cm}^{-1}\right) \\
(\mathrm{CN} \text { dan } \mathrm{NH})\end{array}$ & 1525,69 & $1500.00 \mathrm{~cm}-1$ & - & $1592,33 \mathrm{~cm}-1$ \\
\hline $\begin{array}{l}\text { III } \\
\left(1300-1200 \mathrm{~cm}^{-1}\right) \\
(\mathrm{CN} \text { dan } \mathrm{NH})\end{array}$ & 1161,15 & $\begin{array}{l}1203 \mathrm{~cm}-1 \mathrm{dan} \\
1089,71 \mathrm{~cm}-1\end{array}$ & $1168,78 \mathrm{~cm}-1$ & $\begin{array}{l}1491,05 \mathrm{~cm}-1, \\
1401,04 \mathrm{~cm}-1 \text { dan } \\
1361,64 \mathrm{~cm}-1\end{array}$ \\
\hline
\end{tabular}

Permata et al. (2016) menghasilkan gugus fungsi yang hampir sama dengan gelatin komersial yang digunakan, terlihat kemiripan gugus $\mathrm{C}-\mathrm{H}, \mathrm{C}-\mathrm{N} \quad \mathrm{C}=\mathrm{O}$ antara kedua sampel gelatin. Pada gelatin percobaan dari tulang ikan lele gugus $\mathrm{C}-\mathrm{H}$ terdapat pada panjang gelombang 2852,52 $\mathrm{cm}^{-1}$ dan 2923,88 $\mathrm{cm}^{-1}$ sedangkan gelatin komersial terdapat pada panjang gelombang $2952,81 \mathrm{~cm}^{-1}$. Gugus fungsional C-N pada pembuatan gelatin dari tulang lele terdapat pada panjang gelombang $970,13 \mathrm{~cm}^{-1}$ dan gugus $\mathrm{C}=\mathrm{O}$ terdapat pada panjang gelombang $1743,53 \mathrm{~cm}^{-1}$. Darwin, Ridhay \& Hardi, (2018) dalam artikelnya menjelaskan terdapat gugus $-\mathrm{OH}$ pada $3396,70 \mathrm{~cm}^{-1}$ dan gugus - NH pada 2379,19 $\mathrm{cm}^{-1}$. Adanya gugus -OH menandakan masih terdapat kandungan air pada proses ekstraksi. Pada penelitian ini, terdapat gugus $\mathrm{OH}$ pada panjang gelombang 3269 $\mathrm{cm}^{-1}$ yang dapat dilihat pada Gambar 4 .

\section{KESIMPULAN}

Penggunaan variasi konsentrasi pelarut asam berupa $\mathrm{HCl}$ pada saat proses perendaman berpengaruh terhadap rendemen yang dihasilkan. Rendemen gelatin tertinggi diperoleh pada perlakuan perendaman dalam $\mathrm{HCl} 7 \%$ yaitu sebesar $1,90 \%$, dengan nilai kadar air 10,16\%, kadar abu 3\%, dan kadar protein $3,25 \%$. Pengujian kadar air dan kadar abu dapat memenuhi syarat Standar Nasional Indonesia No.06-3735 tahun 1995.

\section{DAFTAR PUSTAKA}

Badan Pusat Statistik (BPS). (2015). Statistik Perdagangan Luar Negeri. Jakarta (ID): Badan Pusat Statistik.

Atma, Y., Ramdhani, H., Mustopa, A. Z., Pertiwi, M., \& Maisarah, R. (2018). Karakteristik Fisikokimia Gelatin Tulang Ikan Patin (Pangasius sutchi) Hasil Ekstraksi Menggunakan Limbah Buah Nanas (Ananas comosus). Agritech, 38(1), 56.

Darwin, Ridhay, Hardi, J. (2018). Kajian Ekstraksi Gelatin Dari Tulang Ikan Mujair (Oreochromis mossambicus). Kovalen, 1(4), 1-15. 
Food and Agricultural Organization of the United Nations. (2004). Edible gelatin.

Combined Compendium of Food Additive Specifications, 4(1970), 1-2.

Fransiskha, T. (2016). Optimasi Ekstraksi Gelatin dari Tulang Ikan Tuna (Thunnus albacares). Jurnal Wiyata, 3(1), 11-16.

Fulanah, D. (2012). Pembuatan Gelatin Dari Tulang Ikan Kakap Merah (Lutjanus sp). Skripsi. Jurusan Teknik Kimia Fakultas Teknik Univesitas Sebelas Mater. Halaman : 34.

GMIA. (2019). GMIA, Gelatin Handbook. Gelatin Manufacturers Institute Of America, 27.

Gunawan, F., Suptijah, P., \& Uju. (2017). Ekstraksi Dan Karakterisasi Gelatin Kulit Ikan Tenggiri (Scomberomorus commersonii) Dari Provinsi Kepulauan Bangka Belitung. Jphpi, 2(1), 568581.

Hermanto, S., Hudzaifah, M. R., \& Muawanah, A. (2014). Karakteristik Fisikokimia Gelatin Kulit Ikan SapuSapu (Hyposarcus pardalis) Hasil Ekstraksi Asam. Jurnal Kimia Valensi, 4(2), 109-120.

Huda, W., Atmaka, W., \& Nurhartadi, E. (2013). Kajian Karakteristik Fisik dan Kimia Gelatin Ekstrak Tulang Kaki Ayam (Gallus gallus bankiva) dengan Variasi Lama Perendaman dan Konsentrasi Asam. Jurnal Teknosains Pangan, 2(3), 70-75.

Iqbal, C., \& Anam, A. R. (2015). Optimasi Rendemen Dan Kekuatan Gel Gelatin Ekstrak Tulang Ikan Lele Dumbo (Clarias gariepinus sp). Teknosains Pangan, IV(4), 8-15.

Junianto, Haetami, K. \& Maulina, I. (2006). Produksi Gelatin Dari Tulang Ikan Pembuatan Cangkang Kapsul. Tugas Akhir. Fakultas Perikanan dan Ilmu Kelautan Universitas Padjajaran.
Halaman : 65.

Nurilmala, M., Jacoeb, A.M., \& Dzaky, R. A. (2017). Karakteristik Gelatin Kulit Ikan Tuna Sirip Kuning. Jurnal Pengolahan Hasil Perikanan Indonesia, 20(2), 339-350.

Nurmilah, S., \& Mujdalipah, S. (2018). Ekstraksi Gelatin Tulang Ikan Kakap (L. Macolor niger) Menggunakan Metode Asam. Skripsi.

Permata, Y., Widiastri, F., Sudaryanto, Y., \& Anteng, A. (2016). Gelatin dari tulang ikan lele (Clarias batrachus): pembuatan dengan metode asam, karakterisasi dan aplikasinya sebagai thickener pada industri sirup. Jurnal Ilmiah Widya Teknik, 15(2), 146-152.

Pertiwi, M., Atma, Y., Mustopa, A., \& Maisarah, R. (2018). Karakteristik Fisik dan Kimia Gelatin dari Tulang Ikan Patin dengan Pre-Treatment Asam Sitrat. Jurnal Aplikasi Teknologi Pangan, 7(2), 83-91.

Rachmania, R. A., Nisma, F., \& Mayangsari, E. (2013). Ekstraksi Gelatin Dari Tulang Ikan Tenggiri Melalui Proses Hidrolisis Menggunakan Larutan Basa. Media Farmasi, 10(2), 18-28.

Rahmawati, H., \& Pranoto, Y. (2012). Rendemen dan Komposisi Proksimat Gelatin Kulit Ikan Belut dan Lele PAda Keadaan Segar dan Kering. Fish Scientiae, 2(4), 111-123.

Ridhay, A., Musafira, M., Nurhaeni, N., Nurakhirawati, N., \& Khasanah, N. B. (2016). Pengaruh Variasi Jenis Asam Terhadap Rendemen Gelatin Dari Tulang Ikan Cakalang (Katsuwonus pelamis). Kovalen, 2(2).

Samosir, Idiawati, L. D. (2018). Ekstraksi Gelatin Ddari Kulit Ikan Toman (Channa micropelthes) Dengan Variasi Konsentrasi Dari Asam Asetat. Jurnal Kimia Khatulistiwa, 7(3), 104-108. 
Saputra, R., Widiastuti, I., \& Supriadi, A. (2015). Karakteristik Fisik Dan Kimia Gelatin Kulit Ikan Patin (Pangasius Pangasius) Dengan Kombinasi Berbagai Asam Dan Suhu. Fishtech, 4(1), 29-36.

Suptijah, P., Suseno, S. H., \& Anwar, C. (2013). analisis kekuatan gel (gel strength) produk permen jelly dari gelatin kulit ikan cucut dengan penambahan karaginan dan rumput laut. Jurnal Pengolahan Hasil Perikanan Indonesia, 16(2), 183-191.

Suryanti, Hadi, S., \& Peranginangin, R. (2006). Ekstraksi Gelatin dari Tulang Ikan Kakap Merah (Lutjanus sp) Secara Asam. Jurnal Pascapanen Dan Bioteknologi Kelautan Dan Perikanan, 1(1), 27-34.

Windarto, S., Hastuti, S., Subandiyono, Nugroho, R., \& Serjito, S. (2019). Performa Pertumbuhan Ikan Kakap Putih (Lates calcarifer Bloch, 1790) YANG Dibudidayakan dalam Sistem Keramba Jaring Apung (KJA). Jurnal Sains Akuakultur Tropis, 3(1), 56-60. 